\begin{tabular}{|c|c|c|}
\hline $\begin{array}{l}\text { OPEN ACCESS } \\
\text { Vol. } 4 \text { No. 2: } 84-91 \\
\text { Tahun 2021 } \\
\text { Artikel penelitian 唒 }\end{array}$ & $\begin{array}{l}\text { Jurmal Alkuditilestari } \\
\text { E-ISSN: 2598-8204 } \\
\text { http://ojs.umrah.ac.id/index.php/akuatiklestari } \\
\text { DOI: https://doi.org/10.31629/akuatiklestari.v4i2.2488 }\end{array}$ & $Q=$ \\
\hline
\end{tabular}

\title{
Makanan dan Kebiasaan Makan Ikan Sembilang (Plotosus canius) di Perairan Kota Tanjungpinang, Kepulauan Riau
}

\author{
Food and Feeding Habits of Gray-eel catfish (Plotosus canius) in the Waters of Tanjungpinang City, \\ Riau Islands
}

\begin{abstract}
Desi Safitri ${ }^{\circledR}$, Susiana ${ }^{1}$, Ani Suryanti²
${ }^{1}$ Manajemen Sumberdaya Perairan, Fakultas Ilmu Kelautan dan Perikanan, Universitas Maritim Raja Ali Haji, Tanjungpinang, Indonesia 29111

${ }^{2}$ Sosial Ekonomi Perikanan dan Magister Ilmu Lingkungan, Fakultas Ilmu Kelautan dan Perikanan, Universitas Maritim Raja Ali Haji, Tanjungpinang,
\end{abstract}

$\square$ Info Artikel:

Diterima: 24 Agustus 2020

Revisi: 30 Maret 2021

Disetujui: 27 Mei 2021

Dipublikasi: 30 Mei 2021

\section{Keyword:}

Makanan, Kebiasaan Makanan, Ikan Sembilang, Plotosus canius, Tanjungpinang

\author{
$\triangle$ Penulis Korespondensi: \\ Desi Safitri \\ Manajemen Sumberdaya Perairan, Fakultas \\ Ilmu Kelautan dan Perikanan, Universitas \\ Maritim Raja Ali Haji, Tanjungpinang, \\ Indonesia 29111 \\ Email: safitrides7@gmail.com
}

\begin{abstract}
ABSTRAK. Ikan sembilang (Plotosus canius) merupakan salah satu sumberdaya perikanan ekonomis penting yang tergolong dalam family Plotosidae. Penelitian ini bertujuan untuk mengetahui jenis makanan dan rasio panjang usus ikan sembilang pada perairan Kota Tanjungpinang yang meliputi index of preponderance dan indeks kepenuhan lambung. Lokasi sampling ditentukan berdasarkan metode purposive sampling dengan menetapkan 3 stasiun pengamatan dan 3 kali pengulangan yang dilaksanakan pada November 2018 sampai Maret 2019. Analisis data yang dilakukan yaitu rasio panjang usus dengan panjang total, indeks bagian terbesar, dan indeks kepenuhan lambung. Hasil penelitian menunjukkan bahwa nilai rasio panjang usus dan panjang total masing-masing pada sembilang jantan dan betina di ketiga stasiun sebesar 1,24;1,26:1,30 sehingga termasuk golongan omnivora. Index of preponderance berkisar $34,4-50,2 \%$ pakan utama pada umumnya terdiri dari kelompok, kepiting, kerang, udang, siput. Makanan pelengkap ikan sembilang dijumpai seperti detritus dan juga dari spesies Fitoplankton (Mikroalgae) yaitu Acinastrum sp. Chlorella sp. Pediastrum sp. Characium sp. Anabaena sp. Thalasionema sp. Oscillatoria sp. Ceratium sp. Peridinium sp. Navicula sp. Gyrosigma sp.
\end{abstract}

\begin{abstract}
Gray-eel catfish (Plotosus canius) is one of the important economic fisheries resources belonging to the Plotosidae family. The research to determine the type of food habits, and the ratio of the intestinal length of the Gray-eel catfish in the waters of Tanjungpinang City which includes index of preponderance and index of stomach fullness. The sampling location was determined based on the purposive sampling method by establishing 3 observation stations and 3 repetitions which were carried out from November 2018 to March 2019. Data analysis was carried out namely the ratio of intestinal length to total length, largest part index, and stomach fullness index. The results showed that the ratio value of intestinal length and total length of each of the males and females at the three stations was $1.24 ; 1.26: 1.30$ so that it was included in the omnivore group. Index of preponderance ranges from 34.4 to $50.2 \%$. \%. Main feed generally consists of groups, crab, shellfish, shrimp, snails. The complementary food of fish with Gray-eel catfish is found such as detritus and also from Phytoplankton (Microalgae) species namely Acinastrum sp. Chlorella sp. Pediastrum sp. Characium sp. Anabaena sp. Thalasionema sp. Oscillatoria sp. Ceratium sp. Peridinium sp. Navicula sp. and Gyrosigma sp.
\end{abstract}

How to cite this article:

Safitri, D., Susiana, \& Suryanti, A. (2021). Makanan dan Kebiasaan Makan Ikan Sembilang (Plotosus canius) di Perairan Kota Tanjungpinang Kepulauan Riau. Jurnal Akuatiklestari, 4(2): 84-91. DOI: https://doi.org/10.31629/akuatiklestari.v4i2.2488

\section{PENDAHULUAN}

Perairan Seijang, Kampung Madong dan Kampung Bugis merupakan salah satu kawasan pesisir yang terletak di Kota Tanjungpinang. Wilayah pesisir ini memiliki potensi untuk aktivitas perikanan, baik itu perikanan budidaya maupun perikan tangkap. Jenis perikanan tangkap di wilayah ini adalah ikan, udang, siput gonggong, kepiting. Salah satu hasil tangkapan ikan yang banyak ditemukan adalah ikan Sembilang.

Ikan Sembilang merupakan salah satu sumberdaya perikanan ekonomis penting yang tergolong dalam family Plotosidae (Dewanti et al., 2012). Menurut Webber \& Beufort (1913), bentuk ikan Sembilang hampir sama dengan Lele, yang membedakan yaitu sembilang mempunyai 3 patil, satu patil di bagian punggung dan dua lagi di bagian sirip. Hanya 
ada dua jenis sembilang yang hidup di Indonesia dari suku Plotosidae, yaitu sembilang karang yang belang hitam putih dan sembilang yang umum dikenal seperti ikan lele.

Menurut Kottelat et al. (1993), yang menjadi ciri khas ikan sembilang (Plotosus canius) adalah menyatunya sirip punggung ke-2, sirip ekor dan sirip anus serta sisi punggung ikan ini tampak sama dengan ikan Sidat. Ikan sembilang secara taksonomi, termasuk kelas Actinopterygii, ordo Siluriformes, dan famili Plotosidae. Ikan ini masih berkerabat dekat dengan ikan lele, dengan anatomi bentuk tubuhnya yang sangat mirip dengan ikan lele. Lebih lanjut menurut Harteman (2015), ukuran ikan sembilang dapat mencapai $150 \mathrm{~cm}$. Ikan sembilang merupakan jenis ikan karnivora yang memakan ikan-ikan lain yang berukuran lebih kecil. Selain itu, ikan sembilang memangsa hewan laut lainnya yang hidup di dasar perairan, seperti kelompok gastropoda, moluska dan crustasea.

Jenis alat tangkap yang digunakan untuk menangkap ikan Sembilang yaitu jenis rawai dasar. Rawai adalah salah satu alat tangkap yang cukup banyak di operasikan karena menggunakan umpan dan murah dibanding alat tangkap lain bagi nelayan. Hal ini dikarenakan cara pengoperasiannya yang mudah serta daerah penangkapannya yang tidak terlalu jauh dari fishingbase, menurut para nelayan pembuatan alat tangkap rawai dasar lebih mudah.

Kajian informasi dasar yang diperlukan mengenai aspek biologi kebiasaan makan ikan sembilang (Plotosus canius) masih sangat kurang. Kajian yang pernah dilakukan tentang Ikan Sembilang oleh beberapa peneliti yaitu Kebiasaan Makan Ikan Sembilang (Plotosidae) pada Teluk Pengujan, Kabupaten Bintan (Yulianto et al., 2018), Reproduksi dan morfometri Ikan Sembilang (P. canius) betina yang didaratkan di Pengepul wilayah Krobokan Semarang (Dewanti et al. 2012), Beberapa aspek Biologi Ikan Sembilang (P. canius) di perairan Estuari Banyuasin, Sumatra Selatan (Fatah \& Asyari, 2001), Korelasi panjang-berat danFaktor kondisi ikan Sembilang (Plotosus canius) di estuari Kalimantan Tengah (Harteman, 2015).

Kajian mengenai makanan dan kebiasaan makanan ikan sembilang (Plotosus canius) di Perairan Kota Tanjungpinang, Kepulauan Riau perlu dilakukan. Tujuan penelitian ini adalah untuk mengetahui jenis makanan dan rasio panjang usus yang meliputi index of preponderance dan indeks kepenuhan lambung ikan sembilang (Plotosus canius) di Perairan Kota Tanjungpinang, Kepulauan Riau.

\section{BAHAN DAN METODE}

\subsection{Waktu dan Tempat}

Penelitian ini dilakukan pada bulan November 2018 sampai Maret 2019. Pengambilan sampel dilakukan di Perairan Kota Tanjungpinang, Kepulauan Riau. Pengambilan sampel ikan dilakukan pada tiga stasiun yang ditentukan berdasarkan metode purposive sampling, yang terdiri dari Perairan Kampung Madong (Stasiun 1), Perairan Kampung Bugis (Stasiun 2), dan Perairan Seijang (Stasiun 3). Analisis laboratorium dilakukan pada Laboratorium Riset Fakultas Ilmu Kelautan dan Perikanan Universitas Mariti Maritim Raja Ali Haji. Peta lokasi penelitian dapat dilihat pada Gambar 1.

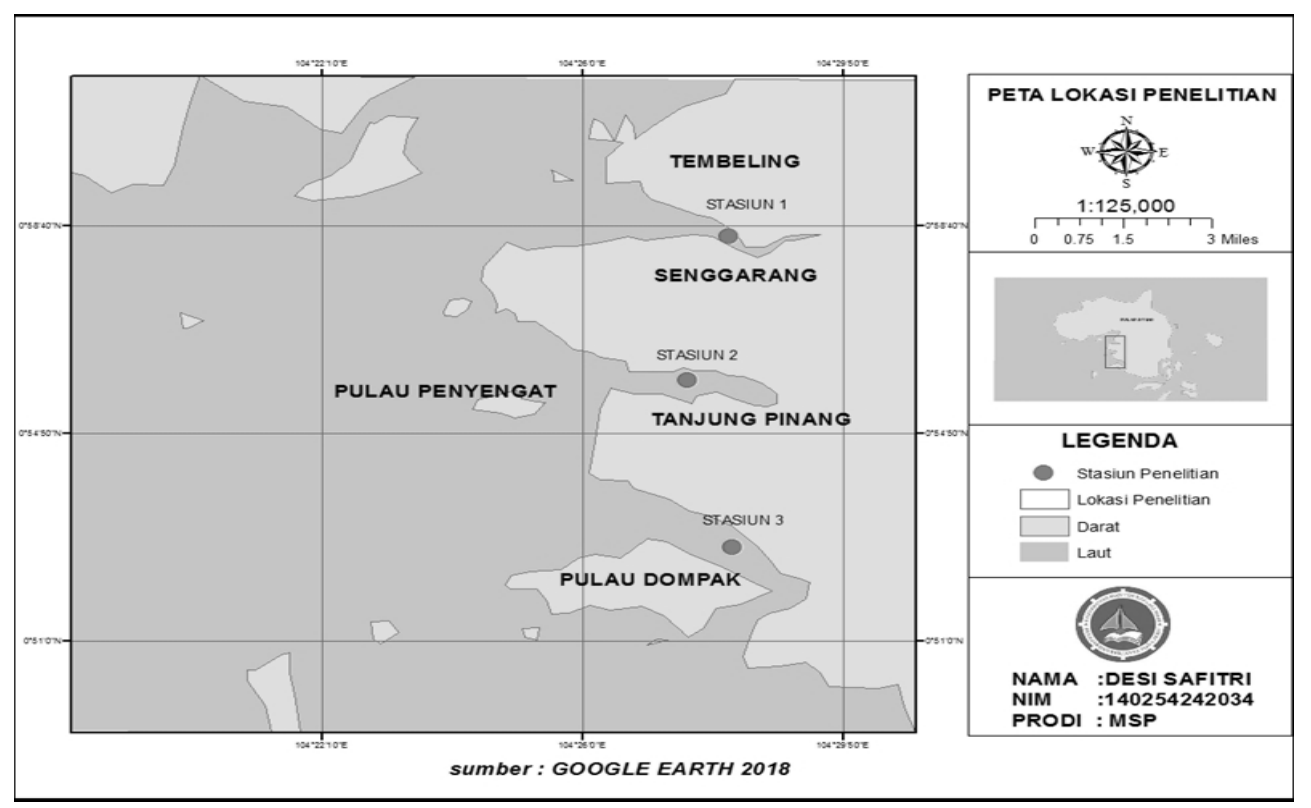

Gambar 1. Peta Lokasi Penelitian

\subsection{Alat dan Bahan}

Alat dan bahan yang digunakan pada penelitian ini adalah kamera, peralatan tulis, timbangan manual, kertas miliameter block, GPS, 1 set alat bedah, peralatan gelas, botol sampel, nampan, kertas label, timbangan digital, ember, sarung tangan, masker, stopwatch, mikroskop, kamera digital, cool box, multitaster dan buku identifikasi plankton. Bahan yang digunakan dalam penelitian ini adalah sampel ikan sembilang dan larutan formalin 5\%. 


\subsection{Prosedur Penelitian}

Prosedur pengambilan dan pengumpulan data pada penelitian ini dilakukan dengan metode purposive sampling. Pengambilan sampel berdasarkan daerah penangkapan ikan Sembilang dan habitat ikan sembilang (Plotosus canius) yang berada disekitaran hutan mangrove sehingga dapat ditentukan 3 stasiun penelitian yaitu Perairan Kampung Madong (Stasiun 1), Perairan Kampung Bugis (Stasiun 2), dan Perairan Seijang (Stasiun 3).

Pengukuran sampel Ikan yang dipilih sebagai sampel diukur panjang dan bobotnya. Pengukuran ikan dengan menggunakan kertas miliameter block mulai dari panjang baku, panjang total serta pengukuran terhadap panjang usus ikan sembilang. Pengukuran bobot ikan dengan menggunakan timbangan digital ketelitian 0,0lg. Ikan yang telah diukur panjang dan bobotnya di bedah dengan metode huruf Y. Usus ikan diambil dan diukur panjang dan volumenya. Volume usus diukur dengan cara memasukkan usus ke dalam gelas ukur yang sudah berisi air kemudian berapa pertambahan setelah dimasukkan usus tersebut sehingga di dapat volume usus. Usus dimasukkan ke dalam botol sampel dan ditambahkan formalin 5\% sampai usus tertutup semua.

Usus dikerik dengan menggunakan pinset. Hasil kerikan usus ikan dimasukkan ke dalam botol dan diberi label. Lalu diencerkan dengan menggunakan aquades sebanyak $10 \mathrm{ml}$, diaduk sampai isi usus tidak menggumpal/padat dan ditambahkan lugol 2-5 tetes lugol. Selanjutnya sampel kerikan usus dimasukkan ke dalam Sedgwick Rafter Counting (SRC) dengan menggunakan pipet tetes sampai penuh dan tidak terjadi gelembung udara dibawah kaca penutup SRC cell. Sampel usus dalam SRC diamati di bawah mikroskop secara total dan pengamatan diulang 3 kali. Identifikasi sampel isi usus menggunakan buku identifikasi Davis (1977).

\subsection{Teknik Pengumpulan Data}

Metode pengambilan sampel ikan sembilang (Plotosus canius) dilakukan menggunakan alat tangkap rawai dasar (long line) dengan bantuan langsung dari nelayan. Ikan Sembilang (Plotosus canius) yang diambil sebanyak 216 ekor secara acak/ stasiun dengan 3 kali ulangan pada setiap stasiun ada yang 72 ekor dan 73 ekor. Dalam penelitian ini tangkapan ikan sembilang yang didapatkan oleh nelayan.

Sampel yang tertangkap terlebih dahulu diukur panjang total (PT) dengan menggunakan alat ukur (calipers), dan ditimbang bobot dengan menggunakan timbangan digital dengan tingkat ketelitian 0,01 g bobot tubuh ikan yang telah diperoleh dicatat. Ikan dibedah diambil lambung dan usus untuk dimasukkan dalam botol sampel yang berisis formalin 5\%. Diberi label pada sampel lambung dan usus dimasukkan ke dalam coolbox untuk dibawa ke laboratorium.

Pengamatan terhadap makanan ikan dilakukan dengan cara mengamati isi lambung dan usus ikan. Sebelum pengamatan isi lambung dilakukan, terlebih dahulu dibersihkan dari formalin dengan air mengalir dan dikeringkan dengan tisu. Lalu melakukan pengukuran volume makanan yang terdapat dalam setiap saluran pencernaan ikan dengan lambung yang berisi makanan yang telah diikat dengan benang pada bagian anterior posterior. Lambung dimasukan kedalam gelas ukur yang berisi $15 \mathrm{ml}$ aquades, kemudian dicatat pertambahan ukuran aquades dalam gelas ukur.

Lambung dimasukkan ke dalam cawan petri lalu lambung di bedah untuk mengeluarkan isi lambung, setelah lambung kosong dimasukan lagi kedalam gelas ukur yang berisi $10 \mathrm{ml}$ aquades dan dicatat pertambahan tinggi aquades tersebut. Hasil pengukuran volume lambung berisi dikurangi dengan volume lambung kosong maka didapatlah volume makanan ikan. Lalu makanan ikan diencerkan menggunakan aquades $10 \mathrm{ml}$. Volume makanan sejenis dicari dengan cara memasukkan sampel makanan sejenis kedalam $15 \mathrm{ml}$ aquades lalu dilihat penambahan volumenya.

\subsection{Analisis Data}

Analisis data yang digunakan adalah hubungan antara panjang usus dan panjang total tubuh ikan, serta jenis makanan yang ada dalam usus ikan untuk mengetahui kebiasaan makanan ikan dan indeks kepenuhan isi lambung. Makanan ikan sembilang dari jenis organisme dianalisis dengan menggunakan buku petunjuk identifikasi fitoplankton The Marine and Fresh-Water Plankton (Davis, 1977). Data yang telah didapatkan akan diolah dan dianalisis secara deskriptif dalam perhitungan, bentuk tabel dan diagram untuk mendapatkan kesimpulan.

\subsubsection{Rasio Panjang Usus dan Panjang Total}

Pengukuran rasio panjang usus terhadap panjang total tubuh ikan sembilang dilakukan dengan cara mengukur panjang total tubuh dan panjang usus kemudian membandingkannya. Rasio panjang usus dan panjang total dianalisis menggunakan rumus Relative Length of Gut menurut Zuliani et al. (2016):

$$
\text { RLG }=\frac{P U}{P T}
$$

Keterangan:

RLG = Panjang usus relatif/Rasio panjang usus dan panjang total

PU = Panjang usus $(\mathrm{cm})$

PT = Panjang total tubuh $(\mathrm{cm})$

Apabila panjang usus relatif $<1$, maka tergolong ikan karnivora. Panjang usus relatif untuk ikan omnivora antara l3, sedangkan untuk ikan herbivora >3 (Nikolsky, 1963). 


\subsubsection{Indeks Bagian Terbesar}

Analisis komposisi makanan yang digunakan yaitu Index of Prepoderance yang merupakan gabungan dari metode frekuensi kejadian dan metode volumetrik Model formulanya sebagai berikut (Effendie, 1979):

$$
I P=\frac{\text { Vi x Oi }}{\sum \text { Vi x Oi }} \times 100 \%
$$

Keterangan :

IP = Index of preponderance untuk satu jenis makanan (\%)

$\mathrm{Vi}=$ Persentase volume satu jenis makanan (\%)

Oi = Persentase frekuensi kejadian satu jenis makanan (\%)

$\Sigma$ viOi = Jumlah Vix Oi dari semua macam makanan

batasan kriteria makanan menurut (Nikolsky, 1963) sebagai berikut:
IP > $40 \%$
= Makanan utama
$4 \% \leq \mathrm{IP} \leq 40 \% \quad=$ Makanan pelengkap
$\mathrm{IP}<4 \% \quad=$ Makanan tambahan

\subsubsection{Indeks Kepenuhan Lambung}

Indeks kepenuhan lambung dianalisa dengan membandingkan berat total ikan dengan berat total lambung. Nilai yang diperoleh dinyatakan dengan persen. Indeks kepenuhan lambung merupakan indikator untuk menunjukkan aktivitas makan dari ikan amatan. Rumus yang digunakan untuk menentukan indeks kepenuhan lambung berdasarkan Effendi (1979):

Keterangan:

$$
\text { ISC }=\frac{B C}{B t} x 100 \%
$$

ISC = Indek kepenuhan isi lambung

BV= = Berat isi lambung

Bt $=$ Berat individu ikan

\section{HASIL DAN PEMBAHASAN}

\subsection{Jenis Makanan Ikan Sembilang (Plotosus canius)}

Jenis-jenis makanan yang di temukan dalam usus ikan sembilang (Plotosus canius) di Perairan Kota Tanjungpinang Kepulauan Riau dapat dilihat pada Tabel 1.

\begin{tabular}{|c|c|c|c|c|}
\hline \multirow{2}{*}{ No } & \multirow{2}{*}{ Jenis Makanan } & \multicolumn{3}{|c|}{ Stasiun } \\
\hline & & 1 & 2 & 3 \\
\hline \multirow[t]{5}{*}{1} & Crustacea & & & \\
\hline & Kepiting & $\sqrt{ }$ & $\sqrt{ }$ & $\sqrt{ }$ \\
\hline & Kerang & $\sqrt{ }$ & $\sqrt{ }$ & $\sqrt{ }$ \\
\hline & Udang & $\sqrt{ }$ & $\sqrt{ }$ & $\sqrt{ }$ \\
\hline & Siput & $\sqrt{ }$ & $\sqrt{ }$ & $\sqrt{ }$ \\
\hline 2 & Detritus & $\sqrt{ }$ & $\sqrt{ }$ & $\sqrt{ }$ \\
\hline \multicolumn{5}{|c|}{ Mikroalgae } \\
\hline \multirow[t]{6}{*}{3} & Clorophyceae & & & \\
\hline & Acinastrum sp. & $\sqrt{ }$ & - & $\sqrt{ }$ \\
\hline & Pediastrum sp. & $\sqrt{ }$ & $\sqrt{ }$ & $\sqrt{ }$ \\
\hline & Characium sp. & $\sqrt{ }$ & $\sqrt{ }$ & - \\
\hline & Anabaena sp. & $\sqrt{ }$ & $\sqrt{ }$ & - \\
\hline & Oscillatoria sp. & $\sqrt{ }$ & - & - \\
\hline \multirow[t]{3}{*}{4} & Dinophyceae & & & \\
\hline & Ceratium sp. & $\sqrt{ }$ & $\sqrt{ }$ & - \\
\hline & Peridinium sp. & $\sqrt{ }$ & $\sqrt{ }$ & - \\
\hline \multirow[t]{5}{*}{5} & Bacillariophyceae & & & \\
\hline & Navicula sp. & $\sqrt{ }$ & - & $\sqrt{ }$ \\
\hline & Gyrosigma sp. & $\sqrt{ }$ & $\sqrt{ }$ & - \\
\hline & Chlorella sp. & $\sqrt{ }$ & $\sqrt{ }$ & - \\
\hline & Thalasionema sp. & $\sqrt{ }$ & $\sqrt{ }$ & - \\
\hline
\end{tabular}

Tabel 1. Jenis Makanan Ikan Sembilang (Plotosus canius)

Keterangan: $(\sqrt{ })$ Ada ditemukan; (-) Tidak ditemukan 
Makanan alami yang diketahui dari usus ikan sembilang dapat menentukan pakan yang baik dan cocok bagi biota. Berdasarkan hasil pengamatan, makanan yang ditemukan di dalam usus ikan sembilang adalah Kepiting, Kerang, Udang, Siput, detritus, Acinastrum sp., Pediastrum sp., Characium sp., Anabaena sp., Oscillatoria sp., Ceratium sp., Peridinium sp., Navicula sp., Gyrosigma sp., Chlorella sp., Thalasionema sp. Hasil analisis jenis makanan ini sejalan dengan penelitian Fatah \& Asyari (2001) beberapa aspek biologi ikan sembilang (P. canius) di perairan estuaria, Kabupaten Banyuasin, Sumatera Selatan bahwa Organisme yang ditemukan dalam saluran pencernaan terdiri dari potongan kepiting, udang, sehingga ikan sembilang dapat digolongkan sebagai ikan karnivora.

\subsection{Sebaran Jumlah dan Ukuran Ikan Sembilang (Plotosus canius)}

Ikan Sembilang yang tertangkap selama penelitian berjumlah 216 ekor yang terdiri dari 125 ekor betina dan 91 ekor jantan. Ikan Sembilang di kelompokkan dalam tiga kelompok ukuran tubuh (besar, sedang, kecil). Kelompok ukuran tubuh ikan Sembilang di ketiga stasiun (Gambar 2, Gambar 3 dan Gambar 4 ).

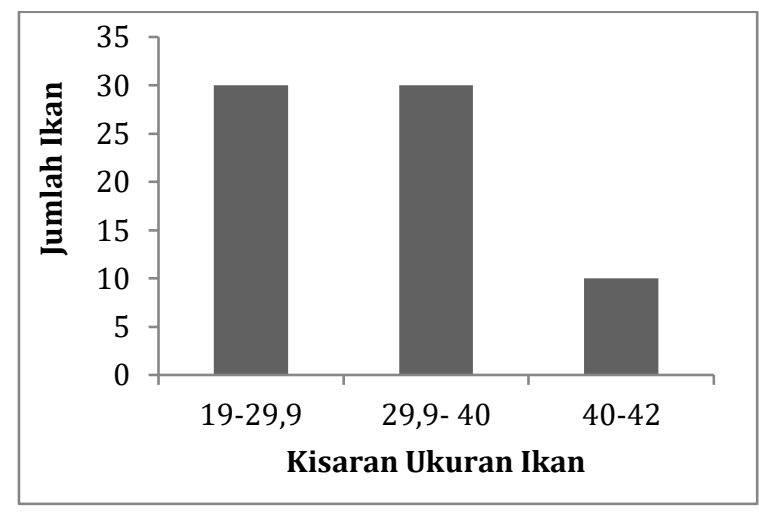

Gambar 2. Kelompok Ukuran Panjang Ikan Sembilang (Plotosus canius) di Stasiun 1

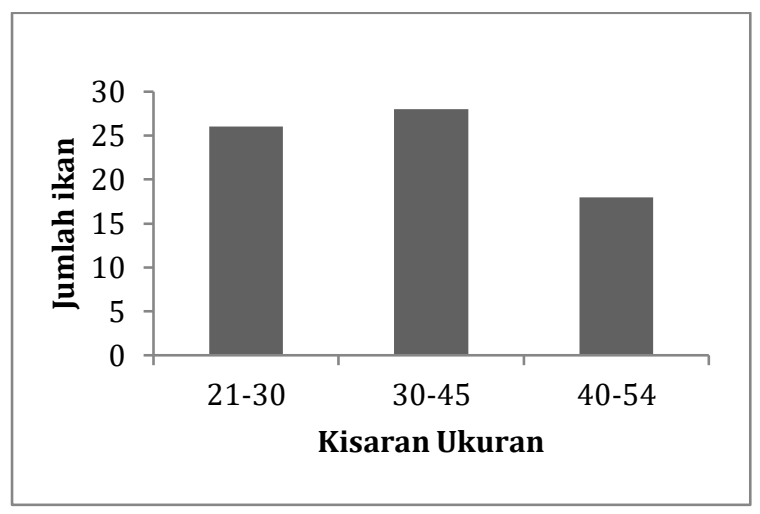

Gambar 3. Kelompok Ukuran Panjang Ikan Sembilang (Plotosus canius) di Stasiun 2

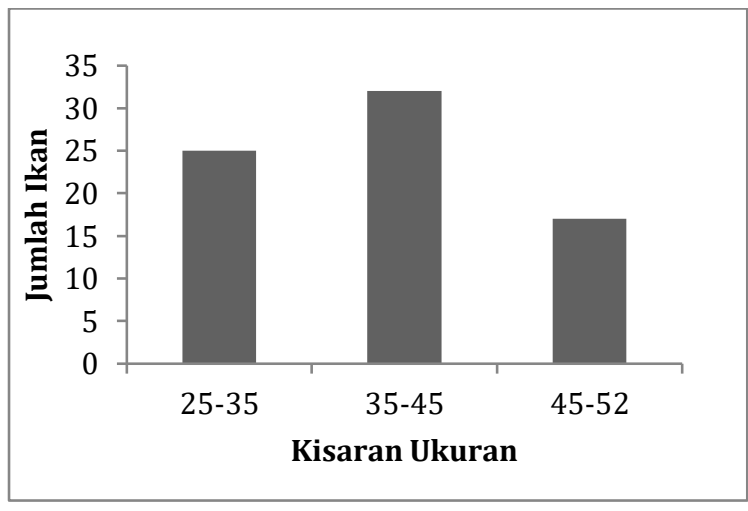

Gambar 4. Kelompok Ukuran Panjang Ikan Sembilang (Plotosus canius) di Stasiun 3

Kelompok ukuran tubuh ikan Sembilang yang paling banyak ditemukan di setiap stasiun adalah yang berukuran sedang $(29,9-45 \mathrm{~cm})$ yaitu sebanyak 90 ekor, diikuti dengan kelompok yang berukuran kecil $(19-29,9 \mathrm{~cm})$ yaitu sebanyak 81 ekor, sedangkan ukuran yang paling sedikit tertangkap adalah ikan Sembilang yang kelompok ukuran besar $(40-54,5)$ yaitu 45 ekor. Pengelompokan ikan disetiap stasiun berdasarkan ukuran kisaran panjang ini bertujuan untuk melihat proporsi jenis makan pada setiap kelompok ukuran (Kresnasari, 2020). Ukuran panjang total ikan sembilang (Plotosus canius) yang tertangkap selama pengambilan pada bulan (November-Maret 2019) di perairan kota Tanjungpinang Kepulauan Riau berkisar antara 19-45,5 cm. Berbeda dengan penelitian Dewanti et al. (2012) yang dilakukan di Kerobokan Semarang, panjang ikan sembilang (Plotosus canius) yang tertangkap berkisar antara $37-70 \mathrm{~cm}$.

\subsection{Rasio Panjang Usus dan Panjang Total Ikan Sembilang (Plotosus canius)}

Rasio panjang usus dan panjang total didapatkan dari perbandingan antara panjang usus dan panjang total (Gambar 5 dan Gambar 6). Pada ikan sembilang, panjang total yang diukur adalah panjang total tubuh. Rasio panjang usus ikan sembilang terhadap panjang total dibedakan berdasarkan 3 kategori yaitu; pemakan tumbuhan (herbivora), pemakan segala (omnivora), dan pemakan daging (karnivora) (Effendie, 2002).

Berdasarkan hasil pengukuran panjang usus ikan sembilang terhadap panjang total tubuh ikan pada ketiga lokasi tersebut dari hasil pengamatan didapatkan hasil rasio panjang usus melebihi panjang total tubuh. Rasio panjang usus terhadap panjang total tubuh (PU/PT) ikan sembilang pada penelitian ini berkisar 1,18; 1,24; 1,26: 1,30. Hal ini sesuai dengan hasil pengamatan jenis makanan yang bervariasi di dalam usus ikan sembilang seperti crustacea, detritus dan 
mikroalga. Hasil ini sejalan dengan Nikolsky (1963), bahwa panjang usus ikan omnivora relatif sama dengan panjang total atau panjang usus berkisar antara l-2 kali panjang total.

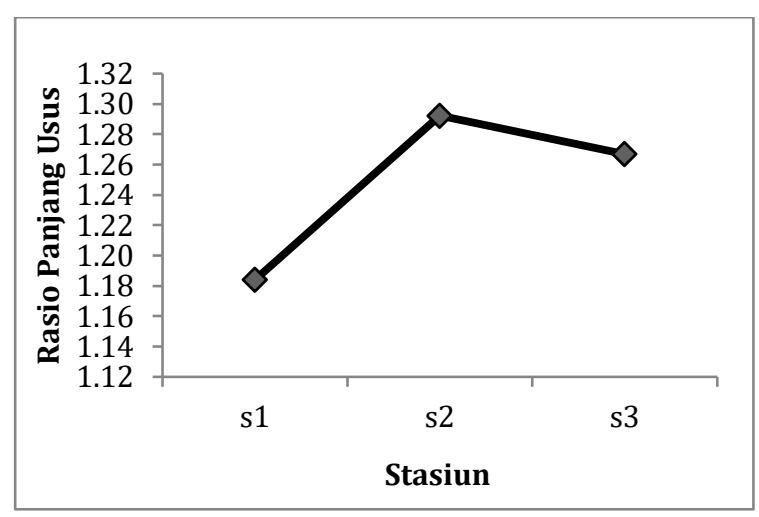

Gambar 5. Rasio Panjang Usus Ikan Sembilang (Jantan)

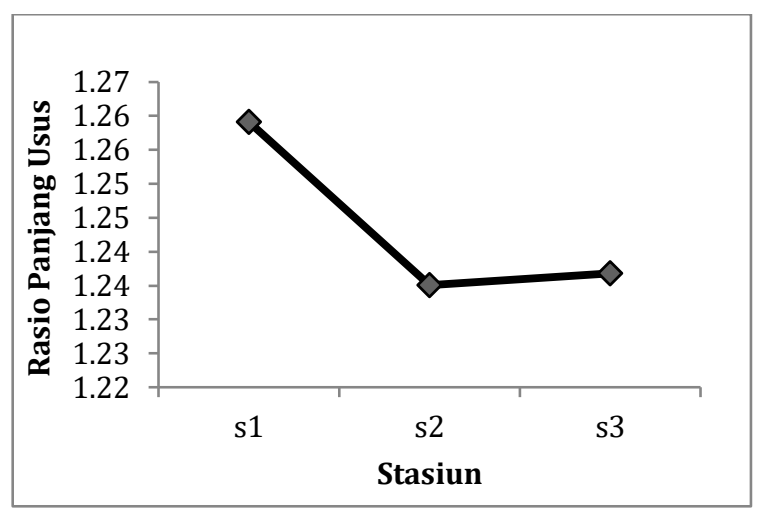

Gambar 6. Rasio Panjang Usus Ikan Sembilang (Betina)

\subsection{Nilai Indeks Bagian Terbesar Ikan Sembilang (Plotosus canius)}

Hasil analisis makanan yang ditemukan pada usus ikan sembilang selama penelitian dianalisis menggunakan nilai Index of Preponderance. Hasil analisis disajikan pada Gambar 6.
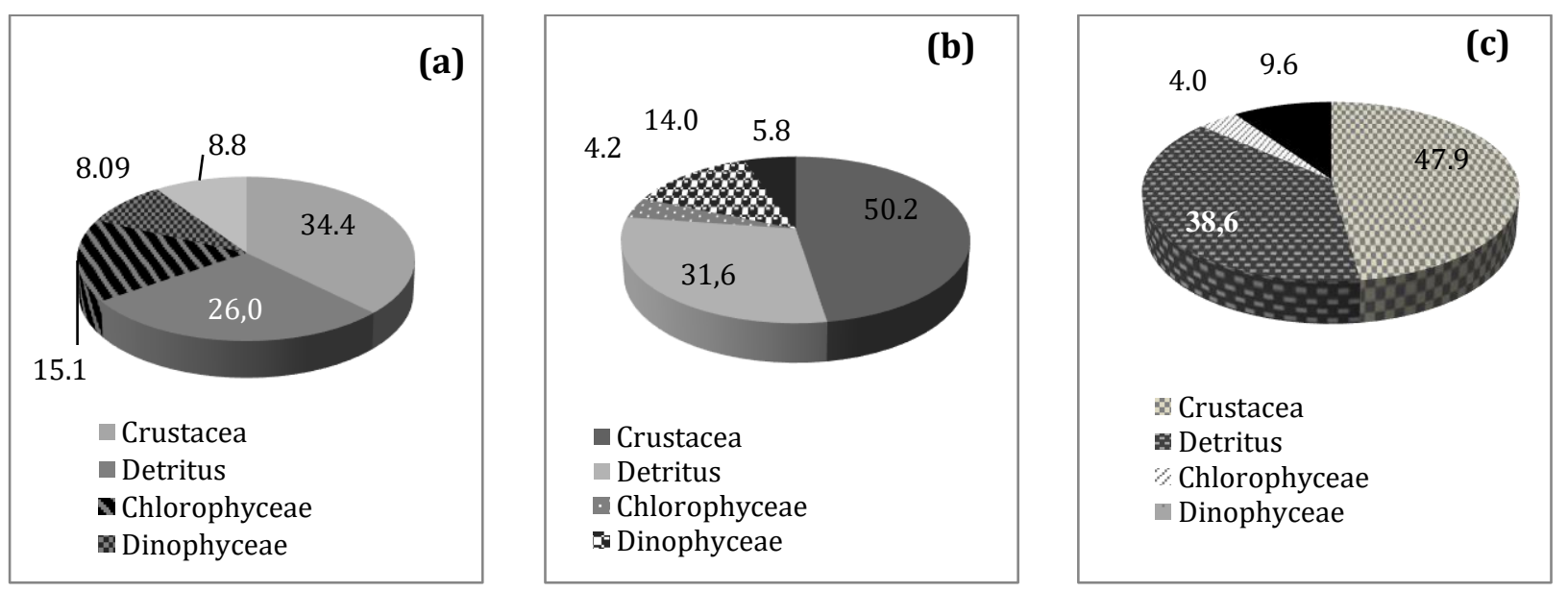

Gambar 6. Indeks Bagian Terbesar (Index of Preponderance) Ikan Sembilang; (a) Stasiun 1, (b) Stasiun 2, dan (c) Stasiun 3

Kelompok makanan dapat dikategorikan berdasarkan nilai indeks bagian terbesar sebagai kelompok makanan utama apabila nilai Indeks Bagian Terbesar lebih besar dari 40\%, makanan pelengkap apabila berkisar 4-40 \% dan makanan tambahan apabila <4\% (Effendie, 1979). Berdasarkan pengelompokan tersebut dapat diketahui bahwa, makanan utama pada ikan sembilang (Plotosus canius) yang ditemukan selama penelitian disetiap stasiun adalah crustacea dengan kisaran nilai 34,4-50,2 \% (Gambar 6), makanan pelengkap ikan sembilang (Plotosus canius) Detritus dengan kisaran nilai 26-38,6\% dan mikroalga yang berasal dari kelas Chlorophyceae dengan kisaran nilai 4-15,1\% mikroalga dari kelas Dinophyceae dengan kisaran 8-14\% dan mikroalga dari kelas Bacillariophyceae dengan kisaran nilai 5,8-9,8\%.

Berdasarkan hasil pengamatan terhadap isi lambung ikan sembilang (Plotosus canius), kelompok Crustasea merupakan organisme yang paling banyak ditemukan. Hal tersebut menunjukkan bahwa makanan utama ikan sembilang (Plotosus canius) adalah crustasea, sesuai dengan penelitian Fatah \& Asyari (2001) yang menyatakan bahwa makanan utama ikan sembilang (Plotosus canius) adalah udang yang tergolong kelompok crustasea sama halnya juga dengan kepiting. Crustasea merupakan organisme bentik yang pada umumnya menjadi makanan ikan demersal seperti sembilang. Meliawati et al. (2014), makanan alami dalam suatu perairan cukup beragam baik dari golongan hewan, tumbuhan maupun organisme mati. Makanan alami yang diketahui dari lambung ikan dapat menentukan pakan yang baik dan cocok bagi biota.

hasil pengamatan Mikroalgae yang ditemukan dalam lambung ikan sembilang didapatkan 3 Class, dengan komposisi terbanyak dari Chlorophyceae 7 genera, Bacillariophyceae 2 genera dan Dinophyceae 2 genera. Hasil penelitian Yulianto et al. (2018) karakter makan ikan sembilang dilihat dari jenis makanan yang termasuk karnivora karena lebih dominan jenis makanannya adalah hewani. Tetapi dari panjang usus ikan Sembilang tidak termasuk karnivora karena tidak memiliki usus yang lebih pendek dari panjang tubuhnya panjang usus ikan sembilang berkisar antara 20 - $84 \mathrm{~cm}$. Menurut Lagler et al. (1977) dan Serajuddin et al. (1998) menyebutkan bahwa ikan yang memiliki alat pencernaan lebih pendek dari panjang total tubuh merupakan salah satu ciri ikan karnivora. 


\subsection{Indeks Kepenuhan Lambung (Index of Stomach Content)}

Indeks Kepenuhan lambung merupakan indikasi untuk mengetahui tingkat konsumsi pakan relatif ikan. Jumlah usus ikan yang teramati 206 usus berisi dan 10 usus kosong. Tingkat kepenuhan lambung ikan sembilang, baik jantan maupun betina memperlihatkan sebagian besar lambungnya terisi oleh makanan di setiap stasiun pengamatan disajikan pada Gambar 7 dan Gambar 8.

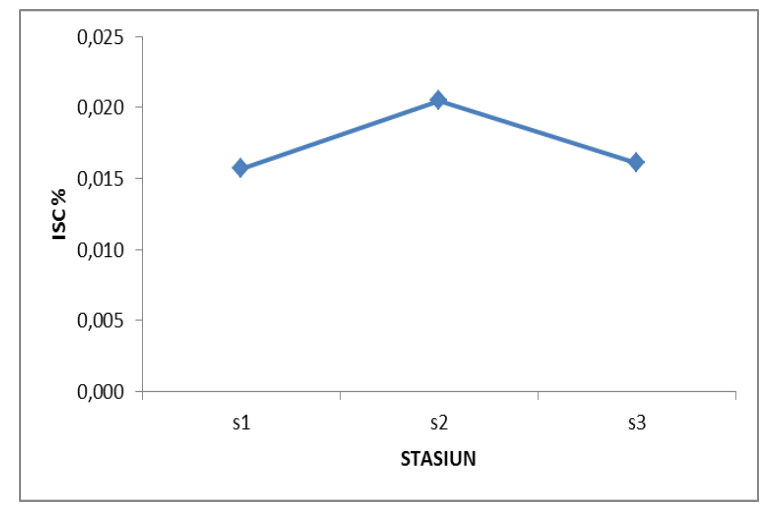

Gambar 8. Indeks Kepenuhan Lambung pada Ikan Sembilang (Jantan)

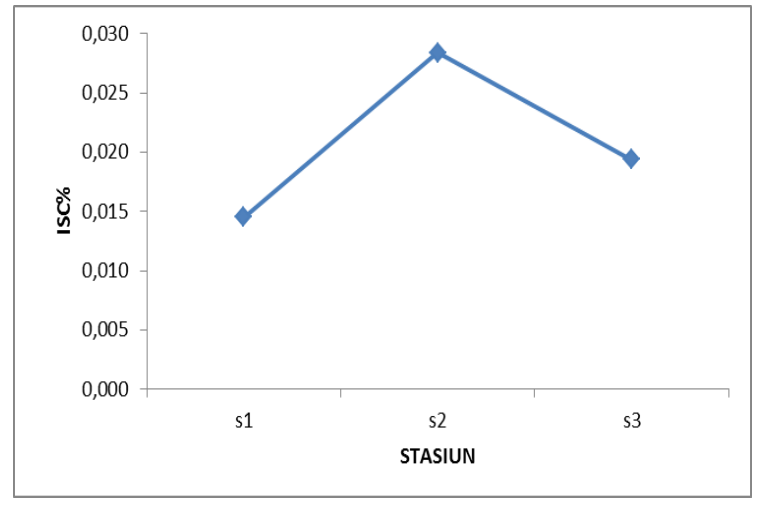

Gambar 9. Indeks Kepenuhan Lambung pada Ikan Sembilang (Betina)

Berdasarkan Gambar 7 dan Gambar 8 menunjukkan bahwa nilai terbesar dari Indeks Kepenuhan Lambung ikan sembilang yang berdasarkan titik stasiun baik pada ikan jantan maupun betina. Nilai Index of Stomach Content tertinggi terdapat pada stasiun 2 dengan nilai rata-rata ISC ikan sembilang (Plotosus canius) jantan dan betina sebesar 0,020 dan 0,030, sedangkan yang terendah pada stasiun satu sebesar 0,014 dan 0,015 ini berarti ikan sembilang lebih aktif mencari makan di stasiun dua. Semakin kecil nilai standar deviasi, maka semakin kecil keragaman isi lambung atau banyak isi lambung yang kosong. Sebaliknya semakin besar standar deviasi semakin banyak lambung yang terisi.

Seperti yang ditegaskan oleh Effendi (2002), ketersediaan makanan akan berpengaruh terhadap pertumbuhan dan kematangan serta keberhasilan hidupnya (survival) tiap individu ikan, sedangkan keberadaan makanan dalam suatu perairan terpengaruh oleh kondisi biotik maupun oleh kondisi abiotik lingkungan seperti suhu, cahaya, ruang dan luas permukaan perairan (Fitri et al., 2019).

Berdasarkan Tabel l, jenis makanan yang paling mendominasi terdapat dalam lambung ikan sembilang di lokasi berpasir dan substrat berlumpur adalah jenis hewan dan dilengkapi dengan organisme lain seperti Mikroalgae berupa Chlorophyceae, Dinophyceae dan Bacillariophyceae di Perairan Kota Tanjungpinang khususnya di ketiga stasiun dengan substrat yang berbeda. Ikan sembilang diduga beradaptasi dengan ketersediaan makanan yang ada di Perairan Kota Tanjungpinang dimana komponen terbesar pada umumnya hewan jenis kepiting.

Umumnya kesuburan suatu badan perairan terhadap kelimpahan makanan selalu berfluktuasi hal ini disebabkan oleh daur hidup, iklim dan kondisi lingkungan yang berubah bergantung musim (Lagler et al., 1977). Effendie (2002) juga menyatakan bahwa perbedaan jumlah organisme yang dimakan ikan terjadi karena perbedaan sebaran organisme tersebut pada masing-masing wilayah. Secara umum kebiasaan makan ikan dipengaruhi oleh beberapa faktor yaitu faktor habitat hidupnya, kesukaan terhadap jenis makanan tertentu, musim, ukuran makanan, warna makanan dan umur ikan tersebut (Nezaputri et al., 2021; Hasnarika \& Kurniawan, 2020).

\section{SIMPULAN}

Jenis makanan yang terdapat pada ikan sembilang (Plotosus canius) adalah crustacea, detritus dan mikroalga dari kelas Chlorophyceae yaitu Acinastrum sp., Pediastrum sp., Characium sp., Anabaena sp., Oscillatoria sp., Bacillariophyceae yaitu Navicula sp., Gyrosigma sp., Chlorella sp., Thalasionema sp., dan Dinophyceae yaitu Ceratium sp., Peridinium sp.

Rasio panjang usus dan panjang total ikan sembilang (Plotosus canius) adalah 1,18; 1,24; 1,26: 1,30 sehingga termasuk kedalam golongan omnivora, dengan perbandingan usus lebih panjang dibanding total panjang tubuh.

Kebiasaan makan ikan sembilang (Plotosus canius) berdasarkan nilai Indeks bagian terbesar di dapatkan bahwa makanan utamanya adalah crustacea. Makanan pelengkapnya detritus dan mikroalga dari kelas Chlorophyceae, Bacillariophyceae dan Dinophyceae.

\section{REFERENSI}

Davis, T.L.O. (1977). Reproductive Biology of the Freshwater Catfish, Tandanus Tandanus Mitchell, in the Gwydir River, Australia I. Structure of the Gonads. Marine and Freshwater Research. 28(2): 139-58.

Dewanti, Y.R., Irwani, \& Rejeki, S. (2012). Studi Reproduksi Dan Morfometri Ikan Sembilang ( Plotosus Canius) Betina yang Didaratkan

Di Pengepul Wilayah Krobokan Semarang. Journal of Marine Research. 1(2): 135-144.

Effendi, M.I. (1979). Metoda Biologi Perikanan. Cetakan I. Yayasan Dewi Sri. Bogor. 112p.

Effendie. (2002). Biologi Perikanan. Yayasan Pustaka Nusantara. Yogyakarta. 163pp. 
Fatah, K., \& Asyari. (2001). Beberapa aspek biologi ikan sembilang (Plotosus canius) di Perairan Estuaria Banyuasin, Sumatra Selatan. Bawal. 3(4): 11-17.

Fitri, N.H.E., Lestari, F., \& Ulfah, F. (2019). Identifikasi Ikan Lokal di Tempat Pendaratan Ikan dan Pola Pemanfaatan Perikanan di Pulau Alai. Jurnal Akuatiklestari. 2(2): 1-9. https://doi.org/10.31629/akuatiklestari.v2i2.984

Harteman, E. (2015). Korelasi panjang-berat dan faktor kondisi ikan sembilang (Plotosus canius) di estuaria Kalimantan Tengah. Jurnal Ilmu Hewan Tropika. 4(1): 6-11.

Hasnarika \& Kurniawan, D. (2020). Pendugaan Stok Ikan Selar (Atule mate) di Perairan Kabupaten Pangkajene dan Kepulauan, Sulawesi Selatan. Jurnal Akuatiklestari. 3(2): 40-47. https://doi.org/10.31629/akuatiklestari.v3i2.3035

Kottelat, M., Whitten, A.J., Kartikasari, S.N., \& Wirjoatmodjo, S. (1993). Ikan Air Tawar Indonesia Bagian Barat dan Sulawesi. Periplus Editions Limited. Jakarta. 293p.

Kresnasari, D. (2020). Hubungan Panjang Berat Tiga Jenis Ikan Introduksi yang Tertangkap di Waduk Penjalin Kabupaten Brebes. Jurnal Akuatiklestari. 4(1): 28-34. https://doi.org/10.31629/akuatiklestari.v4il.2505

Lagler, K.F., Bardach, J.E., Miller, R.H., \& Passino, D.R.M. (1977). Ichthyology. Second edition. John Wiley and Sons Inc., Toronto. Canada.

Nezaputri, N.A., Kurniawan, A., Suryanti, A., Muzahar \& Susiana. (2021). Makanan dan Kebiasaan Makan Siput Gonggong (Laevistrombus turturella) di Perairan Pulau Penyengat Kota Tanjungpinang. OLDI (Oseanologi dan Limnologidi Indonesia). 6(1):1-10.

Nikolsky, G.V. (1963). The Ecology of Fishes. Academic Press. Newbury (GB).

Serajuddin, M., Khan, A.A., \& Mustafa, S. (1998). Food and feeding habits of the spiny eel, Mastacembelus armatus. Journal of Asian Fishery Science. 11: 271-278.

Weber, M., \& Beufort, D. (1913). The Fishes of the Indo-Australian Archipelago. Jilid 2. E. J. Brill ltd. Leiden.

Yulianto, T., Putra, W.K.A., Zulfikar., \& Risma, A. (2018). Kebiasaan Makan Ikan Sembilang (Plotosidae) pada Teluk Pengujan, Kabupaten Bintan. Intek Akuakultur. 2(1): 35-45.

Zuliani, Z., Muchlisin, Z.A., \& Nurfadillah, N. (2016). Kebiasaan Makanan dan Hubungan Panjang Berat Ikan Julung-julung (Dermogenys sp.) di Sungai Alur Hitam Kecamatan Bendahara Kabupaten Aceh Tamiang. Jurnal Ilmiah Mahasiswa Kelautan dan Perikanan Unsyiah. 1(1): 12-24. 